\title{
DVĚ VÝJIMEČNÉ JUBILANTKY V OBORU: JARMILA EMMEROVÁ A EVA MASNEROVÁ
}

\author{
PhDr. EVA KALIVODOVÁ, Ph.D., \\ VYSOKOŠKOLSKÁ PEDAGOŽKA, PŘEKLADATELKA \\ A EDITORKA
}

Těžko by se našly odlišnější osobnosti. Paní doktorka Jarmila Emmerová, skoro záměrně vystupující neakademicky, se stala dobrou vílou mého profesního života. Paní docentka Masnerová, vždy velmi seriózně akademická, se stala mou dlouholetou kolegyní a blízkou osobou. Mým studentským snem od střední školy bylo stát se překladatelkou Z angličtiny, podařilo se mi zázrakem vystudovat obor čeština - angličtina na FF UK v Praze, spíše díky jakési absurditě při přijímacím řízení, protože celá moje rodina byla těžce postižena normalizační perzekucí, a to se se studiem zpravidla vylučovalo. Takovým velkým zázrakem ale samotné studium nebylo, protože probíhalo v tuhých letech 1977-1982 a jedinými skutečně fundovanými a zároveň osvícenými vzdělavateli mi mohli být profesor Hilský, doktor Jindra, profesorka Janáčková a ještě docent Štěpánek. Cesta k překládání pro mne byla dost obtížná, učila jsem poté nejdřív angličtinu děti v kulturním domě na Jižním Městě, pak v Jazykové škole v Praze 1 - což byl jakýsi azyl pro politicky nebezpečné anglisty. Ovšem - učili jsme v dennodenním kontaktu s Mr. Prokopem, spokojeným normalizovaným hrdinou tehdejších učebnic pro jazykové školy, který byl rád, když mohl své znalosti angličtiny uplatnit „mezinárodně“ na brněnském veletrhu. Jediným autentickým výukovým materiálem pro nás byl zpočátku list Komunistické strany Velké Británie Morning Star. Situace velmi podobná tvrdohlavé lásce k angličtině, kterou naplňuje otec hlavního hrdiny Báječných let pod psa Michala Viewegha při šprtání anglických slovíček na záchodě v domě na Sázavě (a bez pasu). Učitelství na střední škole, které jsem vystudovala, mi bylo úřady zapovězeno, stejně tak aspirantura na FF UK, což mi natvrdo sdělil milovaný profesor z anglistiky. Měla jsem totiž i jakési akademické ambice. Dnes už s vnitřním pousmáním vzpomínám, jak jsem po práci v kulturním domě zarputile psala své první odborné př́íspěvky, které mi pomohla ještě v 80 . letech prosadit skvělá redaktorka Irena Malá v liberálním a málo cenzurovaném periodiku Zlatý máj, věnovaném dětské literatuře. Pod svícnem největší tma.

Na Katedru překladatelství a tlumočnictví, později Ústav translatologie FF UK jsem nastoupila roku 1991, spolu s dr. Jiřím Joskem, a strávila tam de facto svůj pracovní život. O konkurzu mne tehdy informoval pan profesor Zdeněk Stř́ibrný, znovu přijatý na FF UK. On i doktorka Jarmila Emmerová měli velmi nesobecký zájem o potenciální anglisty a amerikanisty a snažili se aktivně tehdejší akademickou i intelektuální a kulturní scénu proměňovat. Doufala jsem, že dostanu na KPT př́ležitost vyučovat literaturu, a to se mi splnilo. S paní doktorkou Emmerovou jsem se na tomto pracovišti potkala vlastně letmo, brzy po mém nástupu jej opustila, ovšem setkávaly jsme se na akcích pořádaných Obcí 
překladatelů, $\mathrm{v}$ jejímž čele po roce 1989 stála a pro niž intenzivně pracovala, i při mnoha jiných př́ležitostech. Dr. Emmerová opustila KPT poté, co se diplomaticky zasloužila o tečku za normalizační historií KPT, když v porevolučních volbách vedoucího katedry podpořila mladou a zapálenou anglistku, doktorku Zuzanu Jettmarovou.

$S$ paní docentkou Masnerovou jsem řadu let spolupracovala při výuce anglofonních literatur. Vážila jsem si jí díky jejím znalostem a obrovsky poctivé práci a zároveň - jak to u mladých či mladších v postoji vůči autoritám bývá - jsem se proti jejímu pojetí výuky chtěla vymezovat, hledat si vlastní cestu. Bez Evy Masnerové bych nezískala mnoho podnětů, které jsem at už v jejích intencích, či jiným, svým způsobem rozvíjela. Vzpomínám třeba na hromadu cyklostylovaných literárních textů, které používala se studenty a podělila se se mnou o ně (dnes je tento archaický způsob množení již těžko představitelný); na to, jak jsem se jimi s nedůvěrou probírala o objevila si v nich skvostné povídky Stephena Cranea a Joyce Carrol Oatesové.

Přemýšlet o literatuře mne vždy víc než přitahovalo, po řadu normalizačních let jsem se tím však zabývala dost samotářsky, při omezených kontaktech s literáty a teoretiky či historiky literatury, vybavena nepř́mo jen útržky zapovězeného literárního strukturalismu. Proto se mi skoro nechtělo uvěřit v možnost, kterou mi zprostředkovala doktorka Emmerová jako předsedkyně Obce překladatelů - vyjet v roce 1991 na svůj druhý výlet v životě do anglicky mluvící země (a na Západ), konkrétně do Anglie a Cambridge, kde Britská rada pořádala každé dva roky letní semináře o současné literatuře pro mezinárodní profesní publikum vysokoškolských učitelů, překladatelů a redaktorů. Když jsem jako stipendistka vyslaná OP bydlela v cambridgské Downing College a denně poslouchala přednášky předních anglofonních literátů - byli mezi nimi George Steiner, Dorris Lessing, Hilary Mantel, Michael Holroyd, Salman Rushdie a další - cítila jsem nadějeplně a euforicky, že jsem na jakémsi zázračném „novém začátku“. Nikdy za něj nepřestanu být Jarmile Emmerové a jejímu zájmu a odhodlání pomáhat velmi zásadně jiným vděčná. V životě jsem takových lidí potkala velmi málo a doktorka Emmerové se mi stala silným osobním př́kladem.

V roce 2015 se mně i širšímu publiku naskytla jedinečná možnost setkat se s mnohými nestory českého překladatelství na konferenci „Jan Zábrana: básník, překladatel, čtenáŕc", kterou jsem na půdě Ústavu translatologie FF UK spoluorganizovala. Přišla Eva Masnerová, její̌ osobní morální integrita při „normalizační přijatelnosti“, vysoká intelektuální úroveň a nezměrné znalosti značně ulehčily nakladatelství Odeon vydávat málo ideologicky uvěritelné tituly včetně amerických beatniků; poté umožnily anglistice na KPT velmi důstojně a kvalitně přežít normalizaci. Přišla samozřejmě také Marie Zábranová, která nám při př́pravě konference a následné knihy nesmírně pomohla, a Jarmila Emmerová. Dvě dámy, které se před časem ocitly v tuhé při kvůli českému př̌kladu Prezydenta Krokadýli od Warrena Millera. Je skvělé, že tento překlad je dosud životný, vydávaný a čtený bez ohledu na zjistitelnou identitu překladatele či překladatelů a že obě dámy i Eva Masnerová tehdy kolegiálně nesmírně přispěly do autentické diskuse o „zábranovských“ dobách českého překládání, které českou kulturu drželo nad vodou. Za jedinečné zážitky z této konference stejně jako za mnoho dalších zkušeností, intelektuálních možností a prožitků jsem Jarmile Emmerové a Evě Masnerové velmi vděčná a přeji jim k narozeninám pevné zdraví a velmi zasloužené uspokojení z jejich práce. 